\title{
Evaluating cost-effectiveness in mental health care
}

\author{
MARTIN KNAPP
}

\section{FASHION OR REALITY?}

It is neither fad nor fashion but the harsh economic realities of the late 20th century which prompt the growing interest in the cost-effectiveness or efficiency of mental health care treatments and services. The underlying context in most countries is not new: there are still many people with psychiatric and other health problems not receiving adequate, appropriate or effective care. However, overlaying this context are new social and economic pressures, new pharmaceutical developments and changing political priorities, each of them giving added impetus to the search for cost-effectiveness.

Economic evaluation differs from other evaluative techniques in its examination of a wider range of causes and effects. The common aim of all evaluative research is to enquire if a particular intervention, project or course of action is worthwhile. The difference between economic and other evaluations is the meaning of "worthwhile». Economic evaluations add the resource or cost dimension, but they are not confined to costs. Economists use the term «cost-effectiveness» to mean the examination of both costs and effects (or outcomes) and not as a euphemism for «cheap».

Economic evaluations combine outcome and costs data most commonly in four modes: cost analysis, cost-effectiveness analysis, cost-benefit analysis and cost-utility analysis (Drummond et al., 1987; Knapp, 1995). Each of these modes sets out to

Indirizzo per la corrispondenza: Prof. M. Knapp, Centre for the Economics of Mental Health (CEHM), Institute of Psychiatry, University of London, De Crespigny Park, Denmark Hill, London SE5 8AF (England).

Fax (+44) 171-701-7600. measure costs comprehensively. The differences between them relate to outcome measurement. Simple cost evaluations do not-measure outcomes at all. Cost-effectiveness analyses compare the costs of different policies in achieving an identical outcome (such as a uniform reduction in hospital readmission rates) or different degrees of success (such as cost per readmission avoided). A multivariate cost-effectiveness analysis - rarely undertaken but richly informative - admits more than one outcome and seeks to examine the different cost-outcome links statistically (Beecham $e t$ al., 1991). Cost-benefit and cost-utility analyses value outcomes in monetary and «utility» terms, respectively, but have not yet been much used in mental contexts, partly because their methodological and practical requirements are hard to meet in psychiatry. A common measure of «utility" is the Quality Adjusted Life Year or QALY, but the empirical QALY measures currently available are still only relevant for certain somatic health problems and have not proved useful for psychiatric evaluations (Wilkinson et al., 1992).

In this editorial I am using the term cost-effectiveness to describe a range of economic evaluations.

\section{POLICY AND PRACTICE ISSUES}

Economic evaluations basically address five generic types of policy and practice question (Williams, 1974): What treatment is most appropriate in given circumstances? When should treatment be provided or delivered? Where? To whom? And how? If we look at these questions in turn we can illustrate the potential relevance but (as yet) limited impact of cost-effectiveness evaluations. 
1. What treatment mode is most appropriate in given circumstances?

Many policy and practice issues arise under this head. What, for example, are the cost and outcome consequences of in-patient care with day-patient treatment and community support? What are the effects on patient welfare and on health service and other expenditures of new pharmaceutical products such as clozapine or risperidone for the treatment of schizophrenia (Davies \& Drummond, 1993; Addington et al., 1993). Or are other forms of treatment such as psychological therapies more cost-effective? Is it more cost-effective to provide intensive rather than standard psychotherapy for children with behavioural disorders? Compared to the vast number of "What treatment?» questions faced daily by psychiatrists, other care providers and policy makers, the accumulated quantity of cost-effectiveness evidence currently available is miniscule. Yet the addition of a health economics component to an outcome or efficacy evaluation need not be expensive, compromising or diverting.

\section{When should treatment be provided?}

There have been very few health economics studies of the efficacy and efficiency of preventative measures in relation to mental health problems, though in principle there is no reason why, for example, the cost-effectiveness of psychiatric screening programmes should not be explored, and many interventions for children with conduct disorder or other problems can have major preventive effects (Light \& Bailey, 1993; Robins, 1966; Rutter \& Madge, 1976). There are other "when» questions to address. For example, Burns et al. (1993) examined prompt or early intervention services in South London. People receiving this new service fared better than those receiving conventional care, with a substantial reduction in in-patient stays and lower costs. Generally, however, the timing of mental health treatment has not been examined by health economists.

\section{Where should treatment be provided?}

In almost every European and North American country there has been widespread debate as to the balance between in-patient and community mental health care provision. In Italy, there have not yet been health economics studies of community-based treatment, despite a broad base of clinical research (Tansella, 1991). UK evidence on the long-term care of people with chronic mental health problems gives support to a continued shift away from hospital. Community care costs appear to be lower (Knapp et al., 1993) and outcomes as good or better for matched stayers in hospital (Anderson et al., 1993). Diversion away from in-patient admission can also be cost-effective. The well-known Madison Programme of Assertive Community Treatment was both effective and cost-effective (Stein \& Test, 1980; Weisbrod et al., 1980) and a similar London service, the Maudsley Hospital's Daily Living Programme (DLP) improved symptoms and social adjustment slightly more over a period of 20 months after admission than standard treatment, enhanced patients' and relatives' satisfaction (Marks et al., 1994) and was significantly less costly (Knapp et al., 1994). Randomised, controlled evaluations were used in both Madison and London to compare the innovative services with standard hospital-based care. The studies accommodated the economic dimension without methodological difficulty.

\section{To whom should treatment be provided?}

Only occasionally do evaluations in psychiatry ask this "to whom» question. Yet the "unpackaging» of aggregated data sets can reveal interesting and important inter-patient differences in the effectiveness and cost of standard treatments. Häfner \& an der Heiden (1990) argued that community care was a cost-effective alternative to hospital treatment for people with schizophrenia, but not for everyone. Knapp et al. (1994) found that the new communitybased DLP was more cost-effective than in-patient treatment, but not for one in six of the sample. Some of the controversy over the efficacy of clozapine relates to its targeting during the US trial on particular groups of people. The disaggregation of trial and other data helps to tease out those patient characteristics associated with different outcomes and costs, and this is where a multivariate cost-effectiveness study can be so helpful. It can point out who benefits in what circumstances, or whose costs are greater. Inter-personal comparisons of this kind are inevitable. Decisions about the allocation of mental health treatment resources should therefore benefit from cost-effectiveness evidence. 


\section{How should treatment be provided?}

The fifth generic evaluative question asks how treatment or care is co-ordinated, which is a particular policy and practice emphasis in the UK today. Care programmes and care management are being introduced (Huxley, 1992; Schneider, 1994). Giving community psychiatric nurses wider responsibilities which include the coordination of care packages can be more cost-effective than conventional nursing practice at least in the short run (Muijen et al., 1994; McCrone et al., 1994).

\section{BROADENING THE BASE}

It should be evident that economic evaluations do not and should not seek to replace the judgments of decision-makers, but to inform those judgements. The primary aim of any evaluative research, including any economic evaluation, should be to provide more and better information for policy and practice decisions. Adding cost and cost-effectiveness insights will contribute to those processes. Moreover, the broad design necessary for collecting data relevant to a cost-effectiveness study need be no different to the design chosen for an evaluation of, say, clinical outcomes.

There is still very little cost-effectiveness or other health economics research in psychiatry. The cost-effectiveness dimension has become a more regular feature of mental health care evaluations in the USA over the past decade or so and in the UK comparatively recently. But the baseline of cost-effectiveness knowledge will remain very narrow until health economics contributes to virtually every evaluation. We need to broaden the base, to the benefit of clinicians, researchers, and of course patients.

\section{REFERENCES}

Addington D.E., Jones B., Bloom D., Chouinard G., Remington G. \& Albright P. (1993). Reduction of hospital days in chronic schizophrenia patients with risperidone: a retrospective study. Clinical Therapeutics 15, 917-926.

Anderson J., Dayson D., Willis W., Gooch C., Margolius O., D'Driscoll C. \& Leff J. (1993). The TAPS Project. 13: Clinical and social outcomes of long-stay psychiatric patients after on year in the community. British Journal of Psychiatry, Supplement No. 19, 45-56.

Beecham J.K., Knapp M.R.J. \& Fenyo A.C. (1991). Cost, needs and outcomes. Schizophrenia Bulletin 17, 427-439.

Burns T., Raftery J., Beardsmoore A., McGuigan S. \& Dickson M. (1993). A controlled trial of home-based acute psychiatric services. II: treatment patterns and cost. British Journal of Psychiatry 163, 55-61.

Davies L.M. \& Drummond M.F. (1993). Assessment of cost and benefits of drug therapy for treatment-resistant schizophrenia in the United Kingdom. British Journal of Psychiatry 162, 3842.

Drummond M., Stoddart G.L. \& Torrance G.W. (1987). Methods for the Economic Evaluation of Health Care Programmes. Oxford University Press: Oxford.

Häfner H. \& an der Heiden W. (1990). Effectiveness and cost of community care for schizophrenic patients. Hospital and Community Psychiatry 40, 59-63.

Huxley P. (1992). Social sevices assessment and care management: getting it right. Journal of Mental Health 1, 285-294.

Knapp M.R.J. (ed.) (1995). The Economic Evaluation of Mental Health Care. Ashgate: Aldershot.

Knapp M.R.J., Beecham J., Hallam A. \& Fenyo A. (1993). The cost of community care for people with long-term mental health problems. Health and Social Care in the Community 4, 193-201.

Knapp M.R.J., Beecham J.K., Koutsogeogopoulou V., Hallam A., Fenyo A., Marks I.M., Connolly J., Audini B. \& Muijen M. (1994). Service use and costs of home-based versus hospital-based care for people with serious mental illness. British Journal of Psychiatry 165, 195-203.

Light D. \& Bailey V. (1993). Pound foolish. Health Service Journal, 11 February.

Marks I.M., Connolly J., Muijen M., Audini B., McNamee G. \& Lawrence R.E. (1994). Home-based versus hospital-based care for people with serious mental illness. British Journal of Psychiatry 165 179-194.

McCrone P., Beecham J. \& Knapp M.R.J. (1994). Community psychiatric nurse teams: cost-effectiveness of intensive support versus generic care. British Journal of Psychiatry 165, 218221.

Muijen M., Cooney M, Strathdee G., Bell R. \& Hudson A. (1994). Community psychiatric nurse teams: intensive support versus generic care. British Journal of Psychiatry 165, 211217.

Robins L.N. (1966). Deviant Children Grown Up. Williams \& Wilkins: Baltimore.

Rutter M. \& Madge N. (1976). Cycles of Disadvantage. Heinemann: London.

Schneider J. (1994). Costing the care programme approach. In Economic Evaluation of Mental Health Care (ed. M.R.J. Knapp). Ashgate: Aldershot.

Stein L.I. \& Test M.A. (1980). Alternatives to mental hospital treatment: conceptual model, treatment program and clinical evaluation. Archives of General Psychiatry 37, 392-397.

Tansella M. (ed.) (1991). Community-based Psychiatry: Longterm Patterns of Care in South-Verona. Psychological Medicine, Monograph Supplement No. 19. Cambridge University Press: Cambridge.

Weisbrod B.A., Test M. \& Stein L. (1980). Alternatives to mental hospital treatment: economic benefit-cost analysis. Archives of General Psychiatry 37, 400-405.

Wilkinson G., Williams B., Krekorian H., McLees S. \& Falloon I. (1992). QALYs in mental health: a case study. Psychological Medicine 22, 725-731.

Williams A. (1974). The cost-benefit approach. British Medical Bulletin 30, 252-256. 


\title{
LA MENTE E IL CANCRO. \\ IMSIDIE E RISORSE DELLA PSICHE \\ MELE PATOLOGIE TUMORALI
}

\author{
DI MASSIMO BIONDI, ANNa COSTANTINI
}

\section{E LUIGI GRASSI}

Un libro di 504 pagine. Lire 55.000

Scopo dell'opera è di offrire un manuale pratico e clinico, basato sui dati della letteratura e sull'esperienza personale degli autori per comprendere e trattare gli aspetti psicologici delle persone colpite da cancro.

I capitoli principali includono: la comunicazione della diagnosi (cosa, come, quando e a chi dire, legislazione italiana ed estera, revisione degli studi clinici sull'argomento, il problema del consenso informato), principali tipi di reazione psicologica e psicopatologica alla diagnosi ed ai trattamenti, i problemi della famiglia e dello staff clinico ed interventi per affrontarli, psicoterapie specifiche per pazienti con cancro, possibilità della psicofarmacoterapia per ansia, depressione, insonnia, disturbi psichiatrici su base organica e dolore, panoramica degli strumenti psicologici di valutazione in oncologia. Chiude il volume una rassegna della letteratura su stress, personalità e tumori e sul possibile ruolo del sistema nervoso centrale (psiconeuro-immunologia) sul decorso della malattia.

Il testo è data-oriented con sedici capitoli, oltre 1.500 voci bibliografiche, schemi e figure, numerosi casi clinici ed un elenco delle principali Associazioni Italiane per l'assistenza psicologica al malato oncologico.

\section{In Pensiero Scientifico Editore} Libri e riviste. Nostri contemporanei

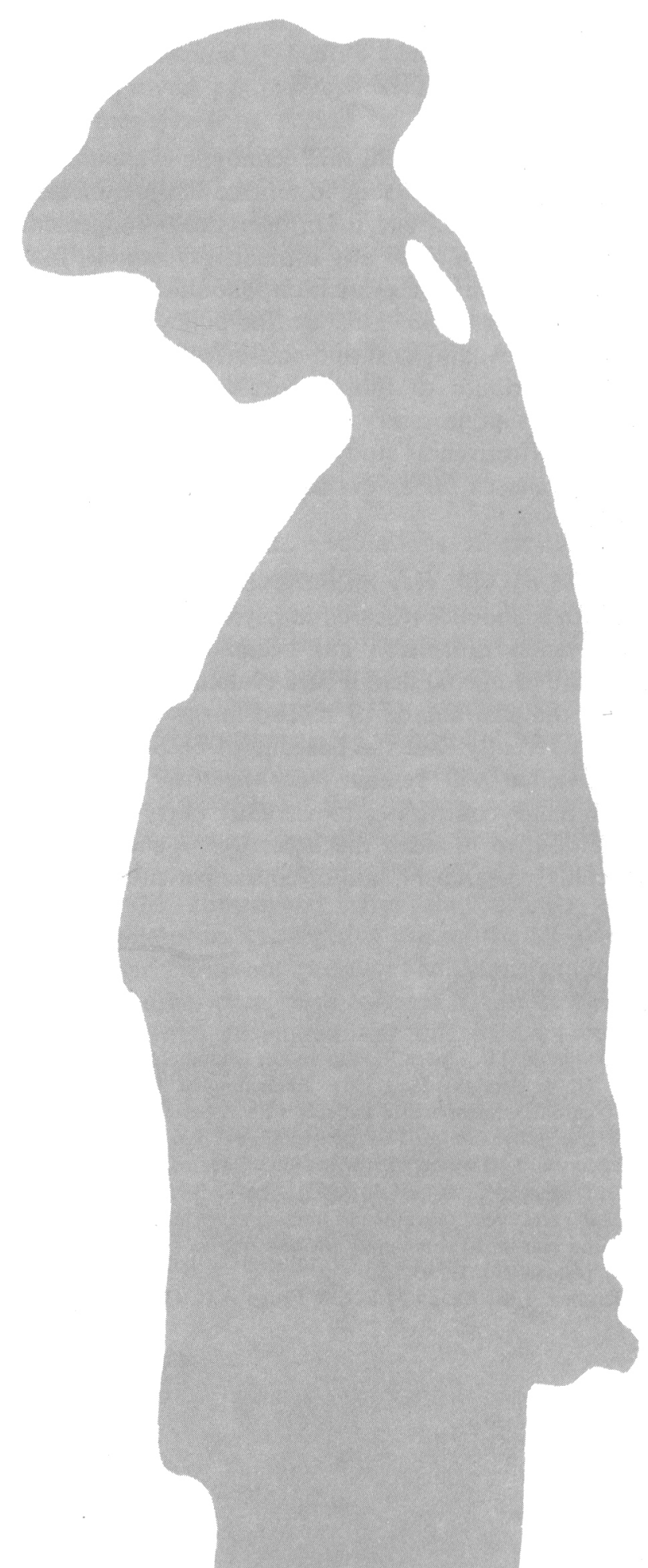

